\title{
Sacerdócio Feminino na Antiga Mesopotâmia
}

\section{Women priests in ancient Mesopotamia.}

\author{
Simone Aparecida Dupla ${ }^{1}$ \\ ${ }^{1}$ Doutora em História pela Universidade Estadual de Maringá. Email: athain celta@hotmail.com. \\ Recebido em 25 de janeiro de 2020; Aceito em 5 de agosto de 2020.
}

DOI: $10.12957 /$ nearco.2020.47993

\section{Resumo}

Este texto visa abordar os papéis exercidos pelas sacerdotisas na Antiga Mesopotâmia, para isso descreveremos brevemente as atividades das principais oficiantes do templo, cuja posição social elevada permitiu que os registros de suas atividades ficassem gravados em textos literários, fórmulas religiosas, correspondências, código de leis, transações econômicas e administrativas.

Palavras-chave: Sacerdotisas; Mesopotâmia; Ofícios religiosos.

\begin{abstract}
This text aims to address the roles played by priestesses in Ancient Mesopotamia, for this we will briefly describe the activities of the main officiators of the temple, whose elevated social position allowed the records of their activities to be recorded in literary texts, religious formulas, correspondence, code of laws, economic and administrative transactions.
\end{abstract}

Keywords: Priestesses; Mesopotamia; Religious crafts.

Muito se tem falado sobre as sacerdotisas na atualidade, do papel das mulheres nos rituais e dentro da comunidade, principalmente com a visibilidade das crenças neopãgas que buscam legitimar suas religiosidades e trazem na sua organização o sacerdócio feminino. Muitas dessas crenças voltam-se ao passado, para os cultos das 
ISSN 1982-8713

divindades femininas e trazem ao presente deusas cultuadas em diversas temporalidades, muitas das quais o culto havia sido sepultado a milhares de anos.

Na Academia, os pesquisadores também abordam as deidades e os papéis das mulheres em diversos contextos dentro de crenças e rituais, principalmente com o advento da História das Mulheres, que vem resgatando já há algum tempo a atuação feminina nos diversos espaços e contextos históricos. Com a Mesopotâmia não seria diferente, uma vez que a diversidade de divindades e a grande gama de atividades executadas pelos grupos femininos vêm chamando a atenção dos estudiosos das Ciências Humanas.

Em minha tese de doutorado dediquei um capítulo às mulheres da Antiga Mesopotâmia e abordei os papéis destas em diversos espaços sociais, principalmente do sagrado e as relações de poder que envolveram as oficiantes femininas dos cultos. Dessa forma, o presente texto traz um pequeno esboço acerca das sacerdotisas e do seu papel junto aos deuses.

Entre as categorias de sacerdotisas abordadas encontra-se a Entu e a Ugbabtu que podemos considerar no topo da pirâmide religiosa e a Ištaritu e a Nadītu, que poderíamos classificar como pertencente ao baixo clero. Descreveremos brevemente as atividades das principais oficiantes do templo, cuja posição social elevada permitiu que os registros de suas atividades ficassem gravados em textos literários, fórmulas religiosas, correspondências, código de leis, transações econômicas e administrativas.

Vale lembrar que a Antiga Mesopotâmia é um espaço acadêmico de permanente disputa ideológica e que está em constante mudança, visto que não apenas as abordagens têm se multiplicado nas últimas décadas, mas também a tradução e descoberta de documentação vêm contribuindo para novos olhares sobre as culturas que se desenvolveram as margens do rio Tigres e Eufrates. Assim, esse texto traz apenas um esboço dos papéis dessas mulheres, uma vez que ainda permanece em aberto as 
discussões, abordagens e compreensão sobre as vivências desses homens e mulheres em relação ao sagrado e profano nos diversos contextos mesopotâmicos.

\section{As mulheres e os ofícios religiosos}

A palavra sacerdote vem do latim (sacerdos= sagrado e otis =representante), e significa representante do sagrado, ou seja, uma autoridade religiosa encarregada de dirigir, orientar e participar do culto e rituais de uma religião. A sacerdotisa, então, seria a representante feminina desse cargo.

Dependendo do grau hierárquico e das funções que desempenham em relação ao sagrado, o (a) sacerdote (tisa) receberá uma denominação específica dentro de cada sistema religioso, assim, os vocábulos que utilizamos para nos referir ao sagrado dizem respeito às denominações da cultura a qual estão inseridos e as atividades características dentro do templo e sob o manto da sacralidade.

Dessa forma, aquele que participa de uma forma ou outra do ofício do divino pode ser considerado um (a) sacerdote (tisa). Na Mesopotâmia, as sacerdotisas que desempenhavam as funções mais altas eram mulheres provenientes da casa real, estavam, portanto, na cabeça dos "templos principais (...) e eram frequentemente e simbolicamente casadas com o deus de seu templo" (SUTER, 2008, p.04), um ofício de caráter mais político que religioso, segundo Claudia Suter (2008).

Ainda segundo a autora, nessa sociedade não havia um termo geral para sacerdote ou sacerdócio, o que dificulta a análise de quem seria o pessoal do culto e os funcionários do templo, visto que não havia uma separação estrita entre as esferas secular e cultual (SUTER, 2008, p.04).

Além disso, os templos não eram apenas locais de culto, mas também empresas econômicas. Assim, para governar a Mesopotâmia de forma administrativa e centralizada, o rei investiu suas filhas como altas sacerdotisas na cabeça de templos principais, e aumentou assim, seu controle da 
economia. O casamento simbólico com uma divindade sancionava esta agenda política em um nível ideológico (SUTER, 2008, p.05).

Tal posição também é sustentada por Allhena Gadotti, em seu artigo sobre os papéis das mulheres no culto durante o terceiro e segundo milênio antes de Cristo. Para essa autora, a função mais importante dizia respeito à sacerdotisa-en, a qual teria dado início a uma tradição que remonta ao reinado de Sargão de Akkad, que colocou sua filha Enheduana como sacerdotisa-en do deus Nanna, na cidade de Ur (GADOTTI, 2016).

A autora destaca que a sacerdotisa-en de Nanna teria sido um cargo de posição política, religiosa e economia crucial para o sul da Mesopotâmia e para a cidade de Ur. Essa entronização da sumo-sacerdotisa, segundo Gadotti seria uma estratégia de domínio, visto que Sargão era o usurpador do trono do rei de Kish, ao qual serviu como oficial, derrotando posteriormente as cidades ao norte do país e seguindo em direção ao sul, onde venceu o rei de Uruk, Lugalzagesi e as cidades adjacentes (GADOTTI, 2016). Assim, por "ser um usurpador de terras estrangeiras, Sargão teve que tomar uma série de medidas para legitimar seu governo, uma delas foi instalar sua filha como sacerdotisa-en de Nanna em Ur, um dos templos mais importantes ao sul da Mesopotâmia" (GADOTTI, 2016, p. 67).

Essa versão das estratégias do monarca explicou também a adoção de Inanna como a divindade protetora de seu reinado, visto que segundo a lenda, Inanna teria se apaixonado pelo rei, uma tentativa de justificar a derrota de Lugalzagesi por este e de colocar os deuses a seu favor. O próprio Sargão aparece na lenda como filho de uma alta sacerdotisa, que não podendo criá-lo o coloca em uma cesta e deixa no rio, onde ele foi encontrado e criado no anonimato até que sua verdadeira descendência foi revelada.

As sacerdotisas partilhavam privilégios e tarefas com outras mulheres reais em relação ao templo, assumiam o cargo de deveres cultuais, estavam presentes nas cerimônias estatais ou festivais cúlticos ao lado do rei, recebiam um rico funeral e oferendas regulares a partir de então (GADOTTI, 2016, p. 5). Nesse sentido, Suter (2008) 
propõe que havia uma divisão de papéis entre as sacerdotisas e as esposas reais, enquanto as primeiras se dedicavam a divindade masculina a qual eram designadas, as segundas se dedicavam às deusas e ao culto feminino.

Essa concepção de que o culto à Deusa, ou às deusas, era parte de uma religião separada para mulheres tem sido questionado por Joan G. Westenholz, visto que o "mais antigo culto da deusa foi liderado por um homem com o mais alto grau responsável pelo culto (o ensi) (WESTENHOLZ, 1998, p. 64). Além disso, muitas suposições sobre as religiões antigas teriam sido baseadas em valores associados às mulheres nas culturas ocidentais, como virgindade, castidade, sexualidade e fertilidade, dos quais apenas os dois últimos possuem importância na cultura mesopotâmica (WESTENHOLZ, 1998, p. 64) e de uma forma muito diferente daquela que percebemos em nossa cultura.

Assim, como o pessoal masculino, as oficiantes femininas do templo tiveram ofícios e posições variadas em relação ao papel que desempenhavam junto à divindade e aquele da sociedade. Vale ressaltar que embora as mulheres na Mesopotâmia tenham tido papéis importantes nos ofícios religiosos, essa importância foi perdendo gradualmente posição com o passar do tempo devido às mudanças políticas que ocorreram e a ascensão de etnias que tinham outra mentalidade sobre a atuação e função das mulheres na sociedade. Pese a isso as considerações de Elena I. Popa sobre o período Babilônico Antigo e o Assírio Médio:

No período Babilônico antigo, sob Hammurabi, uma mulher poderia se divorciar de seus maridos, mas não sem colocar sua própria vida na linha. (...)

As mulheres podiam herdar bens, mas só podiam administrar seus direitos, como o dote e o nudunnu. Além disso, as mulheres precisavam de um contrato escrito para poderem herdar uma parcela da propriedade paterna. As sacerdotisas do tempo experimentaram autonomia semelhante aos homens, mas seus pequenos números em comparação com o grande número de mulheres comuns fazem nadītu e similares, uma exceção. A situação das mulheres na sociedade assíria média requer um mero adjetivo para descrevêlo: "opressivo". As leis de Tiglath-pileser eu sancionava um regime mais 
severo do que o experimentado pelas mulheres durante o período da Babilônia. Uma mulher não podia pedir o divórcio e teve que suportar qualquer castigo que o marido decidiu que merecia. Por outro lado, o homem poderia se divorciar sem qualquer motivo sério sem quaisquer consequências (...) (POPA, 2016, p. 5-6).

Dessa forma, a posição da mulher durante o terceiro milênio e aqueles que o sucederam até o reinado Assírio Médio sofreu uma mudança de status de um sistema quiriarcal em que tinha relativas liberdades para um patriarcal, onde sua existência servia apenas como moeda de troca.

O alto grau de privilégio das sacerdotisas pode ser atestado pela representação destas na glíptica, junto com o rei, elas eram as únicas a serem representadas em postura entronizada em estatutária. Suas imagens nos registros visuais tinham alguns traços característicos, geralmente estavam com os cabelos soltos e portando a insígnia de seu ofício, incluindo a túnica esvoaçante, como as deusas, e um tocado especial que as distinguiam destas. Usualmente elas eram representadas sentadas, como os reis, únicos seres humanos a terem direito a essa regalia (POPA, 2016).

Ainda, segundo Popa, as mulheres comuns tinham o cabelo preso e suas vestes tinham franjas, raramente eram plissados, os cabelos podiam ser cobertos por um véu e costumavam usar uma faixa plana nestes, raramente eram representadas sentadas (POPA, 2016, p.06). As mulheres de status elevado como as sacerdotisas e os membros da realeza, tinham autoridade administrativa considerável, inclusive tendo seu próprio selo e gerenciando funcionários, além é claro de serem letradas, como demonstra, por exemplo, Enheduanna, a sumo sacerdotisa de Nanna, cujos poemas foram divulgados e copiados de forma intensiva e tiveram grande circulação por todo o Império (POPA, 2016, p.07).

O exemplo de Sargão I, de Akkad, ao nomear sua filha como sacerdotisa foi seguida por centenas de anos por outros monarcas, como foi o caso dos reis de Ur, cujos anos de reinado constam a nomeação de suas filhas como sumo sacerdotisas. Além das 
ISSN 1982-8713

filhas, as irmãs do rei também podiam ser nomeadas, o que caracteriza esse cargo como pertencente à elite.

Para Popa:

\begin{abstract}
Essas mulheres não só desempenharam um papel importante no cerimonial religioso, mas estavam constantemente presentes na vida econômica sendo consideradas verdadeiras mulheres de negócios, preocupadas com a venda e arrendamento de terras e imóveis, mas também altamente envolvidas nas atividades da indústria do templo. Os relatórios oficiais de Lagash e Nippur como bem como os registros do templo de outros centros religiosos (principalmente Sippar) incluem certas informações sobre a vida, o trabalho e os interesses particulares dessas senhoras (POPA, 2016, p.07).
\end{abstract}

Em relação às oficiantes femininas do templo, podemos atestar algumas classes de sacerdotisas, ou cargos específicos referentes aos cuidados com os deuses, desses cargos muitos não exigiam que a sacerdotisa habitasse no templo, ou um lugar específico dele, como o caso das Entus (en) que residiam no Gipar, podendo morar fora das dependências do complexo templário e inclusive serem casadas, visto que a castidade não era uma obrigatoriedade para exercer o ofício, embora em alguns casos houvesse a proibição de ter filhos, como veremos.

\title{
Entu ou en: a sumo sacerdotisa.
}

A Entu (alta sacerdotisa) foi a oficiante de culto feminino mais importante da Mesopotâmia, o nome em sumério é nin.dingir (senhora de uma deidade), Ugbabtu em acádio. Ela é dedicada a uma divindade específica e geralmente masculina, assim como seu oposto masculino, o sumo sacerdote está encarregado de uma deidade feminina, embora houvesse exceções à regra ${ }^{260}$. No entanto, são designações diferentes quando aparecem nos textos de Mari e da Antiga Assíria, quando "ambas as figuras femininas aparecem no mesmo texto, a Ugbabtum está em uma classificação inferior a Entu.

${ }^{260} \mathrm{O}$ termo En também pode ser utilizado para a sacerdotisa. 
Ambas deveriam viver na castidade, como foi decidido pelos deuses" (POPA, 2016, p.36). No entanto, a Entu servia apenas a divindades maiores, enquanto a segunda podia servir tanto as maiores quanto as menores.

Encontramos registros da sacerdotisa Entu desde o período sumério até o paleobabilônico, eram escolhidas por presságios colhidos no ano de sua entronização, geralmente o presságio era feito pela extirpação do fígado de um animal. Essas sacerdotisas moravam no Gipar, uma cela construída ao lado da cela da divindade. Em sua morte recebiam honrarias e eram enterradas com as insígnias de sua posição, além de receberem oferendas póstumas.

O tempo que exerciam a função era limitado, sendo que não permaneciam nela até sua morte, mas se aposentavam, embora mantivessem o título, já que recebiam ofertas de aposentadoria da família real (STOL, 2016, p. 563). Essas sacerdotisas eram encarregadas de realizar rituais de purificação, fazer sacrifícios específicos, cuidar do templo, interceder pelo rei, além de cantar canções à divindade ou dividir a cama com o deus. Algumas escreviam poesias como é o caso de Enheduanna já mencionada ${ }^{261}$.

A entronização das Entus era realizada por meio de um festival, o qual levava alguns dias até sua efetiva instalação no Gipar, ou alguns anos após o presságio. Nesse ritual, que durava três dias, a nin.dingir tem todos os pelos do corpo raspados no segundo dia, atestando sua passagem de um status para outro, "a menina deixa de ser apenas a filha de seu pai, ela se torna agora uma autoridade cultual, considerada talvez uma consorte do deus e, portanto, seu status é elevado, tornando-se um membro notável da sociedade em que viveu" (POPA, 2016, p. 38).

\footnotetext{
${ }^{261}$ Essa Entu sacerdotisa, embora consagrada a Nanna, foi devota de Inanna/Ishtar, suas obras escritas em sumério, língua de cultura, louvam a deusa da guerra, adotada por Sargão como protetora de seu reinado. A obra mais importante de Enheduanna foi intitulada de Ninmešara, onde retrata Inanna acima de todos os deuses e pede a intercessão da deusa para retornar ao seu local de direito como Entu, do qual foi destituída pelo rei Lugal-ane.
} 
ISSN 1982-8713

Elena I. Popa discute sobre a futura nin. dingir ter ou não todos os pelos do corpo raspados, ou se esse ritual de transição implicaria apenas em um corte de cabelo específico para a posição a qual assumiria. Conclui pelo segundo, visto que a Entu tinha um penteado especial, que deixava os cabelos pendurados nas costas e usava um acessório na cabeça, a coroa de aga, a qual Enheduanna se queixa que Nanna havia tirado dela, deixando-a com a espada e o punhal na mão.

\begin{abstract}
Meu Nanna \{não me prestou atenção $\}\{1 \mathrm{~ms}$. Tem, em vez disso ) : não decidiu o meu caso\}. Ele me destruiu totalmente em território rebelde. Ašimbabbar ${ }^{262}$ certamente não me pronunciou um veredicto sobre $\mathrm{mim}$. O que é para mim se ele a pronunciou? O que é para mim se ele não o pronunciou? Ele ficou parado em triunfo e me expulsou do templo. Ele me fez voar como uma andorinha da janela; Estou esgotando minha força vital. Ele me fez atravessar os arbustos espinhosos das montanhas. Ele me tirou da legítima \{coroa\} \{( $1 \mathrm{~ms}$, em vez disso:. ) Vestuário\} da en sacerdotisa. Ele me deu uma espada e uma adaga, dizendo-me: "Estes são ornamentos adequados para você" (ETCSL, c.4.07.2, linhas 91-108).
\end{abstract}

Posteriormente a esse ritual de passagem, recebia o trono (cadeira) no qual se sentava e o qual a acompanharia em suas funções religiosas, além dos presentes de seus parentes e dos anciãos da cidade. No último dia do festival, a nin.dingir deixava a casa de seu pai e era instalada no templo, no local designado para ela. A saída da casa paterna dava-se como aquela do casamento, sua cabeça era coberta como a da noiva, e suas criadas a abraçavam como tal, sua cama era preparada no local onde viveria daí em diante, e antes de dormir sua irmã lavava seus pés (POPA, 2016).

A partir disso a sacerdotisa viveria para o seu deus, buscando agradá-lo, estabelecendo ofertas regulares, fazendo ritos que tornassem o reinado de seu pai ou seus negócios favoráveis, realizando libações, ofertas e oferendas à divindade, podia executar reformas no templo ou ampliações. Também cuidava do cemitério das antigas sacerdotisas (POPA, 2016, p. 36).

262 O que se eleva brilhante, um apelativo do deus lua Nanna. 
ISSN 1982-8713

Popa também acredita na hipótese de que "este ofício não era apenas sobre responsabilidade religiosa, mas também utilizado como ferramenta política, a fim de melhorar, através dos meios cultuais, o prestígio e a autoridade da família real e manter seu controle sobre os principais templos" (POPA, 2016, p. 43), opinião a qual compartilho, visto que o controle do templo influenciava nas decisões estatais ou ao menos garantia que grupos opositores se mantivessem em silêncio, no entanto essa questão não pode ser vista apenas como uma jogada política, uma vez que buscava a harmonia do corpo social, mas como um processo de aproximação entre o sistema templário e estatal de diversas cidades sob o comando centralizado de um único monarca.

Sobre o ritual do casamento sagrado, a controvérsia ainda é grande sobre a mulher que desempenhava tal papel, o certo era que salvo exceção não poderia ser uma Entu, visto que esta era proibida de ter filhos, no entanto não creio que isso possa ser relacionado às práticas sexuais. Mesmo proibidas de procriar, algumas Entus tiveram filhos, pelo menos é que diz a lenda sobre o nascimento de Sargão, que menciona este como filho de Enantuma, a En do deus Nanna, e cujo nascimento foi mantido em sigilo, assim, como as circunstâncias das concepções dessas crianças.

Nesse sentido, concordo com Popa, sobre a prática sexual das sumosacerdotisas, embora, houvesse interdição sobre ter filhos, estes poderiam ser adotivos ou fruto de sexo ocasional, mas estas não exigiam relações sexuais rituais (POPA, 2016, p. 46). É interessante notar que a criança era identificada apenas como filho da Entu, esta não perdia o status ou o cargo, e tendo seu filho um selo próprio demonstra que este não teria sido excluído ou rejeitado, ou que amparado pela família real, o filho da sacerdotisa, adotado ou não, estaria a salvo da exclusão social.

O papel da Entu sacerdotisa se destaca em relação às outras atividades executadas pelo restante do pessoal templário, ela era a que tinha a posição mais alta, vivia no templo, em um espaço reservado para este fim, gerenciava libações e rituais, o 
ISSN 1982-8713

fato de ser de família real, escolhida desde o ventre como atestam alguns hinos, não destitui essa mulher de sabedoria e conhecimentos próprios do seu oficio, por isso não concordo com as colocações de Elena I. Popa (POPA, 2016, p. 42) sobre suas virtudes serem irrelevantes, já que seu destino tinha sido escolhido antes do nascimento. As funções de comando exigem conhecimento, preparo e aptidão, e não creio, que alguém intelectualmente medíocre, embora nascido da elite, pudesse executar tal ofício, e acreditar que todos os membros da elite nasciam perfeitos e sábios me parece acreditar em contos de fadas.

Além isso, segundo Marten Stol, o processo de entronização era demorado, sendo que uma sacerdotisa podia ser oficializada anos depois de ter sido escolhida por presságios (STOL, 2016, p. 569). O fato de ser escolhida desde antes de seu nascimento, demonstra que essas mulheres foram preparadas desde a tenra idade, foram domesticadas para seu ofício, no qual eram entronizadas com alegria visto que foram preparadas durante toda sua infância e adolescência.

\section{A ugbabtum, a nadītu e as outras no sacerdócio feminino}

A sacerdotisa Ugbabtu, assim como a Entu era designada pelo sumeriograma nin.dingir, o que sustenta seu alto grau de status, sendo a exceção quando este ocorre nos textos assírios e os textos antigos de Mari. Como a Entu, a Ugbabtum também era escolhida por presságios do fígado e entronizada pelo monarca, quanto uma Entu falecia, uma Ugbabtu era instalada, o que a colocaria como segunda em comando. Sua função não era solitária, podemos encontrar diversas Ugbabtum servindo a mesma divindade e sendo supervisionada por uma Entu (POPA, 2016, p. 47).

Marten Stol acredita que tanto Entu como Ugbabtu seriam sinônimos, assim como as Entus não podia ter filhos, uma prescrição encontrada no mito de Atram-Hasis. As sacerdotisas deviam ter uma vida exemplar, ser castas e intocáveis, até mesmo um beijo Ihes era proibido sob pena dela e daquele que cometeu tal ato ser punidos com 
NEARCD: Revista Eletrônica de Antiguidade 2020, Volume XII, Número II - ISSN IS82-8713

Núcleo de Estudas da Antiguidade - NEA

Universidade do Estado do Rio de Janeiro

ISSN 1982-8713

morte ${ }^{263}$. Como a Entu, a Ugbabtu também recebia um dote ao ser entronizada no templo, como uma mulher consagrada, essa sacerdotisa devia "ser tratada com respeito, protegida de qualquer dano, porque ferir a propriedade do deus foi considerada uma ofensa grave e um devoto definitivamente pertencia à divindade a quem foi consagrada" (POPA, 2016, p.49).

Quando a guerra vencia a cidade onde elas serviam a divindade, essas mulheres não eram desrespeitadas, mesmo quando eram enviadas como espólios de batalhas eram "tratadas com respeito e poupadas da vergonha de serem enviadas com as mulheres comuns para a casa de tecelagem" (POPA, 2016, p.51), no geral eram devolvidas aos seus templos e seus ofícios após acordos, ou porque tirar aquilo que pertence a um deus, mesmo não sendo ele o da predileção do rei era um sinal de desrespeito que os monarcas preferiam não enfrentar por medo da fúria das deidades voltar-se contra eles. Um exemplo disso é atestado pelo rei Zimri-lim, que devolve as sacerdotisas para o templo de Kulmiš, pertencente ao deus Adad:

Zimri-Lim consultou a sua rainha sobre fornecer as ugbabātum roupas novas (talvez como uma compensação pela humilhação de ser levada como saque de guerra) e enviá-las de volta com dois carros com mulas para ele reinstalá-las e apaziguar a divindade. Essa atitude pode ser um exemplo perfeito para a antiga crença da Mesopotâmia de que qualquer adversidade é causada por pecados que podem ter irritado os deuses e como uma punição que "viraram a cara" do pecador (POPA, 2016, p.51).

Isso atesta a importância dessas mulheres para a comunidade as quais pertenciam e sua posição privilegiada dentro do complexo templário. A Ugbabtu ao longo do tempo e do espaço se constituiu como uma atividade versátil, em alguns lugares sua atuação se aproximava ao da sacerdotisa Nadītu.

A sacerdotisa Nadītu foi atestada como parte do pessoal feminino do templo durante do Segundo Milênio, havia duas classes de oficiantes, as que não poderiam

${ }^{263}$ Segundo Stol a sacerdotisa era queimada, assim como o homem com o qual pecara. 
NEARCD: Revista Eletrônica de Antiguidade 2020, Volume XII, Número II - ISSN IS82-8713

Núcleo de Estudas da Antiguidade - NEA

Universidade do Estado do Rio de Janeiro

ISSN 1982-8713

contrair matrimônio (Nadītus de Šamaš e Ninurta) e aquelas que recebiam permissão para casar-se, no entanto não tinham permissão para ter filhos. As Nadītu eram "na sua maioria membros da elite e foram consagradas ao deus patrono de uma cidade: Šamaš (em Sippar), Marduk (na Babilônia) ou Ninurta (em Nippur)" (POPA, 2016, p.52). Essas sacerdotisas constituíam uma classe que não estava limitada a uma cidade, mas foram encontradas em vários locais durante o período Paleobabilônico, elas não eram classificadas separadamente, mas em conjunto (POPA, 2016).

Ao contrário das duas tratadas anteriormente, essa classe não se constituía apenas de filhas e irmãs de reis, mas podiam ser provenientes de famílias abastadas, de sacerdotes, militares ou escribas. Elas eram encarregadas de fazer orações diante das divindades para suas famílias, como uma espécie de oferta viva a estar sempre diante dos deuses. Aquelas que tinham esposo não moravam no Gagûm, o claustro do templo, mas fora dele, geralmente junto à elite ao qual pertenciam.

Diferente das duas primeiras que deixavam suas famílias e pertencia à divindade, a Nadîtum não abandonava seu antigo nome como filha de alguém, mas o título era colocado depois, ou antes, do seu nome (ex: Niš-îni [šu], filha d'Ab [îyatum], nadîtum de Šamaš ou Iltani, nadîtum de Šamaš, filha Sîn-mubalit), além disso, mantinham seu papel dentro da família após a consagração e sua importância na vida social.

Popa ressalta o direito do pessoal feminino do culto expresso no código de Hammurabi:

Elas devem receber um dote consistindo em ativos móveis e imóveis, os últimos assumindo a forma do chamado "dinheiro do anel" que poderia ser usado pelas devotas, conforme desejassem, sem restrições. Além desses ativos, tinham direito com a receita de alimentos de seus parentes, independentemente das circunstâncias, caso contrário, receberiam uma parcela da propriedade paterna igual à de um herdeiro masculino. Como elas não tinham permissão para alienar qualquer propriedade herdada, usavam o dinheiro do anel para aumentar seus rendimentos e estavam envolvidas em vários tipos de atividades econômicas, geralmente envolvendo a venda e o 
empréstimo das terras ou casas que elas podiam comprar com o dinheiro ganho como resultado de seus investimentos (POPA, 2016, p.58).

Esses direitos e atividades fora do complexo templário demonstram certo grau de mobilidade dessas mulheres que podiam gerir e aumentar seus bens, no caso de não terem herdeiros, muitas vezes adotavam um membro feminino da própria família, como uma sobrinha que muitas vezes seguia seus passos, assim, seus bens retornavam a família paterna.

As Nadītus estavam envolvidas com os festivais das divindades as quais serviam, como o de Šamaš, que ocorria durante os meses de dezembro/janeiro e o dia em memória das Nadītus que haviam falecido, além do ritual de consagração de novos membros que geralmente ocorria dentro do último festival (POPA, 2016, p.59). Essas sacerdotisas não eram autorizadas a realizar quaisquer rituais sozinhas, eram supervisionadas e executavam ações e gestos simples, mas sempre sob o olhar das superiores, estavam sempre orando diante de seus deuses, isso não significa que mesmo as clausuradas mantivessem o tempo todo diante da divindade, mas que dedicavam a elas parte importante de seu dia.

Popa (2016) acredita que aquelas que não moravam dentro do complexo templário possivelmente iam até ele pelo menos duas vezes ao dia, pela manhã a noite, ou realizavam suas orações nos altares domésticos, muitas "famílias decidiram dedicar mais de uma filha aos deuses, considerando que essa relação íntima entre o devoto e a deidade traria saúde e prosperidade para todos os membros da casa" (POPA, 2016, p.64).

Segundo Gadotti, a Lukur suméria encontra diversos equivalentes em acádio, entre eles, a Nadītu, mas isto não significa que não houvesse diferenças entre estes dois ofícios, e que o papel da primeira seria mais complexo que da última (GADOTTI, 2016, 
NEARCD: Revista Eletrônica de Antiguidade 2020, Volume XII, Número II - ISSN IS82-8713

Núclea de Estudas da Antiguidade - NEA

Universidade do Estado do Rio de Janeiro

ISSN 1982-8713

p.69). O vocábulo Lukur aparece já no I período Dinástico, em textos de caráter administrativos, como correspondente a esposa de uma divindade.

No período de Ur III, ele se torna um epíteto comum para as mulheres reais. Assim, as esposas do monarca passam a ser identificadas como Lukur, no lugar do termo padrão sumério, Dam. Gadotti coloca que a palavra adquiriu significados diversos de acordo com os contextos, podendo designar, não somente a esposa do monarca, mas também uma classe de sacerdotisas, "algumas das quais podiam casar e ter filhos e outras que não poderiam fazer devido às responsabilidades culturais" (GADOTTI, 2016, p.71).

Outros ofícios e posições femininas surgiram durante o período Paleobabilônico, entre eles, a Gadištu, Ištaru, entre outras. Essas classes de sacerdotisas, segundo Elena Poppa, ao que diz respeito à literatura, poderiam estar envolvidas na prostituição cultural, ideia que é contestada por vários estudiosos na atualidade, como Julia Assante, cujos estudos atestam que não há evidências sólidas que sustentem tal teoria. A kar.kid/harimtu, para Assante (1998), constituiria uma categoria legal e não uma categoria profissional, que corresponderia a mulher não casada, aquela que solteira permaneceu na casa de seu pai, mas que constituiria mesmo assim, um sujeito de direito.

Embora o harimtu possa se referir a mulheres solteiras fora da autoridade patriarcal, deve-se lembrar que o entu, nadītu, ugbabtu, qadištu e kulmašitu não casadas foram consideradas membros do agregado familiar do pai mesmo após a sua consagração, embora se tornando economicamente independente (ASSANTE, 1998, p.71).

O que a autora pressupõe é que essas mulheres poderiam ter sido qualquer coisa, de virgem à prostituta, fato também que não pode excluir que algumas fossem oficiantes em papéis relacionados à fertilidade e a sexualidade (ASSANTE, 1998, p.70). É interessante notar, como alguns autores fogem dessa perspectiva em relação ao desempenho sexual feminino no templo, uma postura atrelada ao contexto religioso e social aos quais estes estudiosos estão inseridos. Há uma dificuldade enorme de crer, 
atestar ou aceitar que em outras temporalidades mulheres e homens tinham formas diversas de contato com o sagrado, que não envolvia apenas um ofício distante e formal dos serviços do divino, mas uma aproximação que se dava de forma que hoje nossa mentalidade construída nas religiões judaico-cristãs não permite admitir.

Já o termo Kezertum, diz respeito a mulheres geralmente associadas ao harimūtum, embora ainda não se possa afirmar que tipo de categoria esta representava, se legal, descritiva ou profissional. No período neo-assírio estava relacionada ao culto de Ištar e "mesmo que a afiliação de kezertum com a prostituição e o culto de Ištar apareça apenas em obras literárias, deve-se lembrar de que esse tipo de documentos refletiram as tradições e as atitudes do tempo e espaço a que pertenciam" (POPA, 2016, p. 73).

Nos arquivos de Mari, está relacionada ao harém real e a um tipo especial de musicista. O papel dela nas atividades do templo não está claro, não se pode afirmar ou negar que participava da prostituição cultual, se poderia ter sido uma cabelereira, visto que a raiz de seu nome diz respeito a um tipo especial de penteado curto ou se era uma artista voltada à música.

Outra oficiante de culto feminino ainda mal interpretada foi a Qadištu, equiparado ao seu homólogo hebraico qedešâ, traduzido como prostituta sagrada, mas cujas evidências não são suficientes para ratificar tal pressuposto. Já a Ištaritu, divide o título de nu.gig, que é usado para designar algumas divindades femininas, como Ninmah, Ninisina e Inanna, cuja tradução variou no tempo, recebendo diversas interpretações como hierodula, prostituta de culto, útero interditado, expressões que, segundo Poppa, remetem aos rituais de cunho sexual (POPA, 2016, p.79). A Qadištu geralmente era consagrada pelo pai a uma divindade masculina, especialmente o deus Adad. Ela podia casar ou ser celibatária, a primeira opção Ihe conferia status social, visto que ser casada a tornava esposa de um homem, a segunda, mesmo que solteira podia 
ter filhos, o que aponta para certa liberdade sexual dessas mulheres, cuja castidade não era obrigatória.

Marten Stol coloca que a Qadištu, era uma mulher consagrada que não morava em um convento (claustro) no período Babilônico Antigo, o termo é traduzido por ele como "mulher santa". Para o autor, o termo nu.gig (intocável), está relacionado com duas categorias de mulheres religiosas, a Qadištu e a Ištarītu (aquela que pertence a Ištar), o que se adequa perfeitamente à uma sacerdotisa. O fato de não habitar no santuário, não constituía empecilho para qualificá-la como sacerdotisa, visto que ela cumpria um dever específico com o templo, e tinha sido escolhida por seu pai para tal oficio (STOL, 2016, p. 609-12).

Stol acredita que a Kezertu era uma prostituta do templo, e que a imagem favorável da Qadištu se deve a sua relação como sacerdotisa do deus Adad, fato que não foi agraciado a primeira, cujas funções, segundo o autor, estiveram relacionadas ao ofício de parteira e a amamentação remunerada. Ainda segundo o autor, os príncipes eram entregues ainda crianças ao templo de Ištar, onde eram amamentados pelas Ištarītus, que representavam os aspectos maternos da Deusa (STOL, 2016, p. 612). Essa colocação pode justificar a adoção de alguns reis do título filhos de Ištar, mas não parece provável que relacione esta deusa com aspectos maternos, os quais ela não possuía.

O estatuto social dessas mulheres mudou de contexto para contexto, sendo que ser casada as tornava respeitadas, mas manter-se solteira não foi visto com bons olhos no final do Segundo Milênio. O que é certo é que estiveram relacionadas ao parto e aos rituais de purificação e exorcismo.

Os documentos que trazem mais respostas dizem respeito aqueles em que as mulheres ocupavam posições mais importantes dentro do ofício religioso, e cujas atividades estavam reguladas pela condição financeira bem-sucedida de sua família, os documentos silenciam ou pouco aborda aqueles cujos status social da família não era 
ISSN 1982-8713

proeminente, o que dificulta a descrição e caracterização de todos os ofícios religiosos que as mulheres fizeram parte.

As atividades do clero eram pertinentes ao culto diário, aos cuidados com as estátuas e imobiliário dos deuses, assim como sua contabilidade, os rituais e exorcismos, além das festividades oficiais e particulares. Essas responsabilidades envolviam por vezes o tempo integral dos oficiantes, mas na maioria estes não habitavam o templo, e sim residências nos bairros próximos ao santuário (MARGUERON, 2016, p.380).

As sacerdotisas tiveram um papel atuante na Antiga Mesopotâmia, mas seu poder e influência foram se perdendo ao longo dos séculos. No período de Ur III e Paleobabilônico, que são melhores documentados, verifica-se um aumento das atividades do pessoal templário, caindo posteriormente devido às questões políticas e socioculturais.

As funções e atividades do templo protagonizadas pelas sumo-sacerdotisas resistiram à queda de Ur III até aproximadamente a época de Nabucodonosor (11261105) caindo posteriormente no esquecimento. A última tentativa de restaurar sua função se deveu ao rei Nabônido (555-539) que por meio de uma placa de Nabucodonosor, onde se descrevia uma sacerdotisa, suas funções e indumentária reconstruiu a função dando cargo a sua filha, Enningaldinana, a última sacerdotisa entu (OPPENHEIM, 2003, p.119).

A importância dessas mulheres nos cargos do templo pode ser percebida por meio da mentalidade dos mesopotâmicos em relação a sua atuação junto ao exercício do sagrado, um dos maiores orgulhos dos mesopotâmicos era o fato de haver sacerdócio feminino, a ponto de colocarem como sinal de selvageria ou de primitivismo que os povos estrangeiros não tivessem um clero feminino (BOTTÉRO, 2001, p.149). Assim, para os habitantes da terra entre os dois rios, a existência de grupos femininos no serviço dos deuses era sinal de civilidade e servia como parâmetro para medir outras sociedades, cujas culturas as mulheres não participavam do ofício divino. 
ISSN 1982-8713

\section{Algumas considerações}

Pudemos perceber que a classe sacerdotal estava hierarquizada e isso dizia respeito tanto ao clero feminino quanto o masculino, na cabeça do sistema clerical deste último, por exemplo, encontramos o sumo sacerdote (šangû/išškku), sob seu comando havia outros sacerdotes, como os kalû/gala, encarregados dos hinos de lamentações, pašî̌su, que realizavam as unções, ramku, encarregados das purificações. Havia também o pessoal que trabalhava em outras atividades, mas não era parte do clero (MARGUERON, 2016, p.379), como os assinu, kugarru e kulu's considerados prostitutos sagrados.

O papel das mulheres na sociedade mesopotâmica era complexo e variado, de sacerdotisas a mulheres comuns, elas ocuparam diversos cargos e foram protagonistas em diversos momentos. O texto abordou apenas sua participação no serviço dos deuses e apontou os nichos sociais a que pertenciam essas mulheres, revelando que os espaços que ocupavam nos complexos templários relacionam-se as questões de poder que entrelaçavam o templo e o palácio, política e religião.

As vivências das mulheres mesopotâmicas é um campo de pesquisas em constante expansão, sua atuação junto ao sagrado demonstra que estiveram presentes nas mais diversas áreas sociais, nas quais nem sempre transitavam livremente, mas que é possível perceber suas estratégias para circular nos diversos espaços tanto público quanto privado.

Os cargos ocupados pelas mulheres em relação ao sagrado desconstroem a ideia deste como locus privilegiado de grupos masculinos e levanta diversas questões acerca da mobilidade social das mulheres dentro de espaços sagrados e profanos e dos limites que separam ambos. 
ISSN 1982-8713

\section{Referências}

\section{Documentação}

ETCSL, c.4.07.2. The exaltation of Inana (Inana B). Linhas 91-108. Disponível em: http://etcsl.orinst.ox.ac.uk/cgibin/etcsl.cgi?text=t.4.07.2\&display=Crit\&charenc=gcirc\& lineid=t4072.p1\#t4072.p1. Consultado em junho de 2018.

\section{Bibliografia}

ASSANTE, J. The kar kid/harimtu, Prostitute or Single Woman? A consideration of the Evidence. Ugarit-Forschungen 30, 1998.

BOTTÉRO, Jean. La religión más antigua: Mesopotamia. Madrid: Trota: 2001.

GADOTTI, A. Mesopotamian women's cultic roles in late 3rd-early 2 nd millennia BCE. In: BUDIN, S.L.; TURFA, J.M. Women in Antiquity: real women across the ancient world. New York: Routledge, 2016.

MARGUERON, Jean-Claude. Los mesopotamicos. Madrid: Cátedra, 2016.

OPPENHEIM, A. Leo. La Antigua Mesopotamia: retrato de una civilización extinguida. Madrid: Gredos, 2003.

POPA, Elena. Agency of Women in Mesopotamian Religion of the Second Millennium BC. University of Zurich / University of Bucharest, Faculty of Theology, 2016.

STOL, M. Women in the Ancient Near East. Translated by Helen and Mervyn Richardson. Boston/Berlim: De Gruyter, 2016.

SUTER, C.E. Who are the women in Mesopotamian art from ca. 2334-1763? Rivista di storia, ambienti e culture del Vicino Oriente Antico, vol. 5, 2008.

WESTENHOLZ, J. G. Goddesses of the Ancient Near East 3000-1000 BC. In: GOODISON, L.; MORRIS, Christine. Ancient Goddesses: the myths and the evidence. London: British Museum Press, 1998. 